Volume 8, Nomor 1, 2020: 165-185

\title{
ANALISIS PPK, LITERASI, 4C, DAN HOTS PADA SILABUS DAN RPP MATA PELAJARAN FIKIH
}

\author{
Fatimah \\ UIN Sunan Ampel Surabaya, Jawa Timur, Indonesia \\ mafazayusuf@gmail.com \\ Muhtar Tajuddin \\ UIN Sunan Ampel Surabaya, Jawa Timur, Indonesia \\ muhtartajuddin88@gmail.com \\ Muhammad Ilyas \\ UIN Sunan Ampel Surabaya, Jawa Timur, Indonesia \\ ilyasmuhamad440@gmail.com \\ Abdul Majid \\ UIN Sunan Ampel Surabaya, Jawa Timur, Indonesia \\ ismimajid@gmail.com
}

\begin{abstract}
Abstrak
Tujuan Artikel ini mengungkap kandungan unsur PPK, Literasi, 4C, dan HOTS pada dokumen silabus dan Rencana Program Pengajaran (RPP) mata pelajaran Fikih, khususnya kelas $\mathrm{X}$ semester ganjil. Dengan pendekatan deskriptif kualitatif, dari penelitian yang dilakukan di MAN 2 Pasuruan, Jawa Timur ini diperoleh temuan bahwa; (1) Dokumen RPP tidak sinkron dengan dokumen silabus; (2) Unsur PPK yang terintegrasi dalam silabus dan RPP masih terbatas pada karakter religius; (3) Unsur literasi sudah cukup mendapatkan perhatian; (4) Unsur 4C baru sebatas komunikasi dan kolaborasi. Sementara berpikir kritis dan kreatifitas belum mendapatkan perhatian; (5) Tidak ditemukan unsur HOTS dalam RPP, baik di indikator KD, proses pembelajaran, maupun penilaian.
\end{abstract}

Kata Kunci: PPK; Literasi; $4 C$; HOTS; RPP.

\begin{abstract}
The purpose of this study is to reveal elements of PPK, Literacy, 4C, and HOTS of sillabus and instruction plan of subject Fikih in class $X$ semester odd. By descriptive qualitative approach, from this study that toke place at MAN 2 Pasuruan, East Java, found that; (1) Document of instruction plan is not sincron to sillabus; (2) Elements of PPK which is integrated to sillabus and instruction plan are still limited to religious character; (3) Elements of literacy is paid attention quite enough; (4) Elements of $4 C$ is limited to communication and collaboration. While critical thinking and creativity are not paid attention yet; (5) There are no element of HOTS that can be found in document of instruction plan, in the indicator of KD, teaching-learning process, as well as in the assessment.
\end{abstract}

Keywords: PPK; Literacy; 4C; HOTS; instruction plan. 


\section{A. Pendahuluan}

Proses pendidikan tidak hanya dilakukan dengan mentransfer ilmu dari guru ke siswa akan tetapi siswa harus mampu belajar dari pengalaman langsung atau kehidupan sehari-harinya. Pengetahuan yang dimiliki seseorang terkait dengan pengalaman-pengalamannya (Ainurrahman, 2009 : 17). Sama halnya dengan pelajaran yang lain, mata pelajaran Pendidikan Agama Islam tidak hanya difahami dengan membaca dan menghafal saja, akan tetapi untuk menguasai dan memahami konsep-konsep agama Islam diperlukan keterlibatan siswa secara aktif dalam pembelajaran maupun diskusi kelompok serta penambahan informasi-informasi terkait mengenai agama Islam. Informasi-informasi terkini sangat diperlukan untuk mengetahui bagaimana agama Islam yang seharusnya dengan kenyataan yang ada di masyarakat saat ini.

Pembelajaran agama di Madrasah Aliyah terdiri dari empat mata pelajaran, yaitu: Fikih, Akidah Akhlak, Al-Qur'an Hadis, dan SKI, dan pelajaran agama pendukung lainnya (sesuai lembaga masing-masing). Ilmu Fikih merupakan ilmu yang mempelajari hukum-hukum syara' yang praktis yang diambil dari dalildalil secara terperinci. Pembelajaran Fikih diberikan untuk mengenalkan siswa terhadap bagaimana sesungguhnya hukum Islam. Tujuan utama proses belajar Fikih adalah agar siswa mampu mengamalkan konsep-konsep Fikih dan mampu mengalisis praktek-praktek amalan-amalan syariat di kehidupan sehar-hari berdasarakan konsep-konsep Fikih yang telah dipelajari.

Pembelajaran Fikih di beberapa madrasah masih terpaku pada membaca dan menghafal tanpa adanya proses yang mampu menimbulkan rasa ingin tahu siswa sehingga siswa tidak tergerak aktif dalam mencari informasi maupun aktif bertanya. Salah satu faktor penyebabnya adalah proses pembelajaran yang diaplikasikan kurang mampu menimbulkan rasa ingin tahu siswa sehingga berdampak pada keaktifan siswa dalam belajar baik pada saat di madrasah maupun di rumah. Hal serupa terjadi dalam pembelajaran Fikih di MAN 2 Pasuruan. Selama ini di MAN 2 Pasuruan bahan ajar yang digunakan adalah buku wajib terbitan Kementrian Agama yang pada sampul depannya tertulis terintegrasi PPK dan HOTS. Namun apakah proses pembelajaran di kelas sudah mengintegrasikan 
PPK dan HOTS tersebut? Hal inilah yang akan ditelusuri lebih lanjut dalam penelitian ini. Selain itu, aspek penting lain yang perlu diintegrasikan ke dalam pembelajaran abad 21 adalah literasi dan 4 C. Berdasarkan hasil wawancara dengan kepala sekolah dan pengampu guru fikih MAN 2 Pasuruan,pembahasan artikel ini akan fokus kepada analisis kandungan PPK, LITERASI, 4C, dan HOTS pada SILABUS dan RPP mata pelajaran Fikih kelas X Semester Ganjil Madrasah Aliyah Negeri 2 Pasuruan.

Adapun metode yang digunakan dalam mengkaji pembahasan ini adalah metode Deskriptif Kualitatif. Metode penelitian adalah cara yang digunakan oleh peneliti dalam mengumpulkan data penelitiannya (Arikunto, 2006:160). Melalui artikel ini berusaha untuk melaporkan keadaan objek yang diteliti sesuai dengan apa adanya, yaitu menggambarkan atau mendeskripsikan tentang kondisi silabus dan RPP yang digunakan oleh guru Fikih MA Negeri 2 Pasuruan Kelas XII Semester 1. Dalam hal ini penulis melakukan analisis kelengkapan komponen integrasi PPK, Literasi, 4C, dan HOTS, sistematika penyusunan dan komponen isi RPP yang disusun oleh guru Fikih MA Negeri 2 Pasuruan Semester 1. Teknik pengumpulan data dengan melakukan analisis terhadap dokumen silabus dan RPP yang digunakan guru Fikih MA Negeri 2 Pasuruan Semester 1. Analisis dokumen dilakukan dengan mempelajari dokumen-dokumen yang telah dikumpulkan. Dokumen yang dikumpulkan adalah dokumen silabus dan RPP guru Fikih yang dijadikan pedoman pembelajaran selama semester satu Tahun Pembelajaran 2019/2020. Kemudian diambil 1 dokumen dokumen silabus dan 4 dokumen RPP sebagai perwakilan untuk dianalisis. Dokumen silabus dan RPP berupa soft file yang didapat langsung dari guru Fikih MA Negeri 2 Pasuruan. Data yang diperoleh kemudian dianalisis berdasarkan tabel kelengkapan integrasi penelahaan komponen isi silabus dan RPP

\section{B. Pembahasan}

Fikih adalah ilmu tentang hukum Islam yang disimpulkan dengan jalan rasio berdasarkan dengan alasan-alasannya (Nasrudin Razak, 1985 : 251). Sedangkan definisi Fikih secara terminologi ialah suatu ilmu yang mempelajari bermacam-macam syari'at atau hukum Islam dan berbagai macam aturan hidup 
bagi manusia, baik yang bersifat individu maupun yang berbentuk masyarakat sosial atau pengetahuan tentang hukum- hukum syari'at yang berkaitan dengan perbuatan dan perkataan mukallaf (mereka yang sudah terbebani menjalankan syari'at agama), yang diambil dari dalil-dalilnya yang bersifat terperinci, berupa nash-nash al-Qur'an dan al-Sunnah serta yang bercabang darinya yang berupa ijma'dan ijtiha (Hasbi Ash Shiddieqy, 1987 : 17).

Mata pelajaran Fikih adalah bahan kajian yang memuat ide pokok yaitu mengarahkan peserta didik untuk menjadi muslim yang taat dan saleh dengan mengenal, memahami, menghayati, dan mengamalkan hukum Islam sehingga menjadi dasar pandangan hidup (way of life) melalui kegiatan bimbingan, pengajaran, latihan serta pengalaman peserta didik sehingga menjadi muslim yang selalu bertambah keimanan dan ketaqwaannya kepada Allah SWT. (Depag RI Ditjen Kelembagaan Agama Islam, 2004 : 2). Secara garis besar mata pelajaran Fikih terdiri dari dimensi pengetahuan, keterampilan, dan nilai-nilai keagamaan.

\section{Pembelajaran dan Keterampilan Abad 21}

Pada abad 21 ini telah lahir gerakan global yang menyerukan model pembelajaran baru. Para pakar pendidikan sepakat bahwa pendidikan harus diubah untuk menyikapi tuntutan zaman yang semakin kompetitif. Perubahan ini penting untuk memunculkan bentuk-bentuk pembelajaran baru yang dibutuhkan dalam mengatasi tantangan global yang kompleks. Pendekatan tradisional yang menekankan pada hafalan atau penerapan prosedur sederhana tidak akan mengembangkan keterampilan berpikir kritis atau kemandirian peserta didik. Setiap individu harus terlibat dalam pembelajaran berbasis inkuiri yang bermakna, memiliki nilai kebenaran dan relevansi, untuk mengembangkan keterampilan berpikir tingkat tinggi yang diperlukan peserta didik.

Secara psikologis, istilah karakter (watak) dan kepribadian sering dipergunakan secara bergantian, namun Allport dalam Suryabrata menunjukkan, bahwa biasanya kata kepribadian menunjukkan arti normative. Dia menyatakan "character is personality evaluated and personality is character devaluated". Menurut Ngalim Purwanto (2000: 40), kepribadian bukan hanya mengenai tingkah 
laku yang dapat diamati, melainkan juga termasuk di dalamnya apakah sebenarnya individu itu. Jadi selain tingkah laku yang tampak, juga diketahui motivasinya, minatnya, sikapnya, dan sebagainya yang mendasari pernyataan tingkah laku tersebut.

Karakter (watak) merupakan bagian dari kepribadian (personality); di dalam kepribadian terdapat unsur sikap (attitude), sifat (traits), temperamen dan karakter (watak). Sikap merupakan suatu cara bereaksi (meresepon) terhadap suatu rangsangan (stimulus) yang disertai dengan pendirian dan atau perasaan orang tersebut. Sifat merupakan ciri-ciri tingkah laku yang tetap (hampir tetap) pada seseorang. Temperamen adalah sifat-sifat jiwa yang sangat erat hubungannya dengan konstitusi tubuh, yakni keadaan jasmani seseorang yang terlihat dalam halhal yang khas baginya, seperti keadaan darah, pekerjaan, kelenjar, pencernaan, pusat sarat, dan lain-lain. Temperamen lebih merupakan pembawaan dan sangat dipengaruhi oleh konstitusi tubuh, sehingga sukar diubah dan dididik, tidak dapat dipengaruhi oleh kemauan atau kata hati orang yang bersangkutan. Perbedaan utamanya, sikap merupakan hasil pengaruh dari lingkungan, sedangkan temperamen hampir-hampir tidak dipengaruhi oleh lingkungan, dan sifat berada di tengahtengah, merupakan percampuran antara sifat-sifat pembawaan dan pengaruh lingkungan.

Adapun karakter mengandung pengertian yang lebih luas, yang mencakup pengertian sikap, sifat-sifat dan temperamen. Karakter merupakan struktur batin manusia yang tampak pada tindakan tertentu dan bersifat tetap, baik tindakan itu baik maupun buruk, serta merupakan ciri khas dari pribadi orang yang bersangkutan. Bila temperamen sangat dipengaruhi oleh konstitusi tubuh dan pembawaannya, maka karakter lebih dipengaruhi oleh faktor-faktor lingkungan, seperti pengalaman, pendidikan, intelijensi dan kemauan.

Kerchensteiner dalam Ngalim Purwanto (2000: 145) membagi karakter manusia menjadi dua bagian, yaitu karakter biologis dan karakter intelijibel. Karakter biologis mengandung nafsu atau dorongan insting yang rendah, terikat pada kejasmanian. Karakter biologis tidak dapat diubah dan dididik, Sedangkan karakter intelijibel berkaitan dengan kesadaran dan intelejensi manusia. Karakter 
intelijibel inilah yang bisa dirubah dan dididik. Ia menyatakan bahwa untuk mendidik karakter peserta didik dengan baik, didiklah kemauannya, cara berpikirnya, dan kehalusan perasaan ke arah yang baik.

Penguatan Pendidikan Karakter (PPK) merupakan proses pembentukan, trasformasi, trasmisi dan mengembangkan potensi peserta didik agar berpikiran baik, berhati baik, dan berperilaku baik sesuai dengan falsafah hidup Pancasila. Sudah tentu karakter anak itu merupakan hasil interaksi antara pembawaan dan lingkungan, sehingga dalam Penguatan Pendidikan Karakter (PPK) yang ditekankan bukanlah pembawaan dan lingkungan kulturnya, namun interaksi keduanya.

Terdapat lima nilai utama karakter yang menjadi prioritas Gerakan Penguatan Pendidikan Karakter di Madrasah. Lima nilai karakter tersebut merupakan satu kesatuan utuh yang tidak bisa di pisah-pisahkan, saling mempengaruhi dan saling menentukan dan ditentukan, yakni Religius, Nasionalis, Mandiri, Gotong Royong, dan Integritas (Tim Penyusun PPK, 2016: 13).

Pembelajaran abad 21 dituntut berbasis teknologi untuk menyeimbangkan tuntutan zaman era milenia dengan tujuan. Peserta didik diharapkan terbiasa dengan kecakapan hidup abad 21. Oleh karena itu siswa yang hidup pada abad 21 harus menguasai keilmuan, berketerampilan metakognitif, mampu berpikir kritis dan kreatif, serta bisa berkomunikasi atau berkolaborasi yang efektif, keadaan ini menggambarkan adanya kesenjangan antara harapan dan kenyataan.

Oleh karena itu, pemerintah merancang pembelajaran abad 21 melalui kurikulum 2013 yang berbasis pada siswa. Guru sebagai kepanjangan tangan dari pemerintah di sekolah-sekolah menerapkan pembelajaran abad 21. Di sekolah formal, pembelajaran sudah dituntut untuk menerapkan kemampuan 4C (Critical Thinking, Communiaction, Collaboration , Creativity). Hal ini dapat terwujud cepat tidak hanya tuntutan pada kinerja guru dalam mengubah metode mengajar, tetapi juga peran dan tanggung jawab pendidik non formal dalam membiasakan anak-anak menerapkan 4C dalam keseharian. Untuk mencapai kondisi belajar yang ideal, kualitas pengajaran selalu terkait dengan penggunaan model pembelajaran secara optimal, ini berarti bahwa untuk mencapai kualitas pengajaran yang tinggi setiap 
mata pelajaran harus diorganisasikan dengan model pengorganisasian yang tepat dan selanjutnya disampaikan kepada siswa dengan model yang tepat pula (Singgih, 2017 : 45-50). Keterampilan 4C wajib dikuasai dan dimiliki oleh setiap peserta didik guna menghadapi tantangan abad 21.

Critical thinking (berpikir kritis) yaitu kemampuan siswa dalam berpikir kritis berupa bernalar, mengungkapkan, menganalisis dan menyelesaikan masalah. Di era reformasi critical thinking, juga digunakan untuk menangkal dan memfilter paham radikal yang dianggap tidak masuk akal. Kemampuan berpikir kritis biasanya diawali dengan kemampuan seseorang mengkritisi berbagai fenomena yang terjadi di sekitarnya, kemudian menilai dari sudut pandang yang digunakannya. Kemudian ia memposisikan dirinya, dari situasi yang tidak tepat menjadi situasi yang berpihak padanya.

Communication (komunikasi) yaitu bentuk nyata keberhasilan pendidikan dengan adanya komunikasi yang baik dari para pelaku pendidikan demi peningkatan kualitas pendidikan.

Collaboration (kolaborasi) yaitu mampu bekerja sama, saling bersinergi dengan berbagai pihak dan bertanggung jawab dengan diri sendiri, masyarakat dan lingkungan. Dengan demikian ia akan senantiasa berguna bagi lingkungannya.

Creativity (kreativitas) yaitu kemampuan untuk menghasilkan sesuatu yang baru. Kreativitas peserta didik perlu diasah setiap hari agar menghasilkan terobosan atau inovasi baru bagi dunia pendidikan. Kreatifitas membekali seorang peserta didik yang memiliki daya saing dan memberikan sejumlah peluang baginya untuk dapat memenuhi segala kebutuhan hidupnya.

Penerapan 4C dalam pembelajaran kurikulum 2013 jika benar-benar dilakukan di sekolah akan memberikan dampak yang luar biasa bagi generasi penerus bangsa untuk menghadapi tantangan hidup abad 21.

Disamping 4C, Kemendikbud juga meluncurkan program unggulan Gerakan Literasi Sekolah sebagai upaya pemerintah menjadikan pendidikan berkualitas dengan meningkatkan budaya literasi (membaca dan menulis. Di Dalam Permendikbud Nomor 23 Tahun 2015 telah menyadari pentingnya penumbuhan 
karakter peserta didik melalui kebijakan membaca selama 15 menit sebelum pelajaran dimulai. Kegiatan ini perlu perhatian khusus untuk dilaksanakan secara rutin oleh warga sekolah. Walaupun terlihat mudah, namun sulit dalam mengerjakannya karena kita harus melawan hawa nafsu yaitu rasa malas membaca yang tertanam dalam masing-masing pribadi yang belum terbiasa. Namun, jika kita sudah terbiasa melakukannya ini akan menjadi ringan dan kebiasaan baik untuk membangun karakter anak bangsa yang multiliterat. Semua kalangan perlu bersinergi untuk mensukseskan program pemerintah baik sekolah keluarga dan masyarakat.

Literasi merupakan proses kompleks yang melibatkan proses pembangunan pengetahuan sebelumnya, budaya dan pengalaman untuk mengembangkan pengetahuan baru dan pemahaman yang lebih mendalam Sejalan dengan hal tersebut konsep literasi juga mengalami perkembangan diantaranya yaitu penggunaan berbagai media digital baik di kelas, sekolah, tempat tinggal maupun masyarakat. Kini istilah literasi telah berkembang menjadi multiliterasi. Multiliterasi merupakan kemampuan membaca, menulis puisi, membagi, melukis, menari, menulis novel ataupun kemampuan berkontak dengan berbagai media yang memerlukan literasi (Rustaman, 2007). Dengan demikian, literasi dipandang sebagai kegiatan yang bermakna dari berbagai media.

Memasuki abad 21 penguasaan sains dan teknologi adalah kunci keberhasilan generasi bangsa dalam menghadapi persaingan global. Sains adalah bagian dari pendidikan sebagai wahana bagi peserta didik untuk menguasai secara kontekstual dan mempraktekkannya dalam kehidupan sehari-hari. sains berperan dalam membangun karakter masyarakat dan bangsa dikarenakan kemajuan pengetahuan yang amat pesat, keampuhan proses yang dapat ditransfer pada bidang lain, dan terkandung muatan nilai dan sikap di dalamnya. Adapun literasi sains adalah bagaimana pemahaman tentang sains menjadikan solusi dalam pengambilan setiap keputusan yang dihadapi.

Kemampuan dalam memproses operasi mental yang meliputi pengetahuan persepsi dan penciptaan. Suatu kemampuan berpikir merupakan sebuah kemampuan dalam menggunakan pikiran untuk mencari makna dan pemahaman tentang sesuatu, 
mengeksplorasi ide, mengambil keputusan, memikirkan pemecahan dengan pertimbangan terbaik, dan merevisi permasalahan pada proses berpikir sebelumnya. Sebagaimana yang telah dijelaskan bahwa 'thinking skill is an ability in using mind to find meaning and comprehension on something, exploration of ideas, making decision, problem solving with best consideration and revision on the previous thinking process" (Zaenal Arifin, 2017).

Kemampuan berpikir terbagi atas dua bagian, yaitu kemampuan berpikir tingkat rendah (Low Order Thinking Skill atau LOTS) dan kemampuan berpikir tingkat tinggi (Higher Order Thinking Skill atau HOTS). Keterampilan berpikir tingkat tinggi siswa merupakan salah satu barometer tingkat intelektualitas bangsa. Sebagai agent of change, siswa hendaknya mampu menunjukkan jati dirinya dengan cara-cara yang intelektual, bermoral, dan elegan. Oleh karena itu, pada abad 21 ini proses pembelajaran yang dilaksanakan di setiap jenjang pendidikan harus benarbenar diperhatikan, agar dapat menghasilkan lulusan yang kompeten.

HOTS adalah kemampuan berpikir kritis, logis, reflektif, metakognitif, dan berpikir kreatif yang merupakan kemampuan berpikir tingkat tinggi. Kurikulum 2013 juga menuntut pembelajaran untuk sampai pada tahap metakognitif yang mensyaratkan siswa mampu memprediksi, mendesain, dan memperkirakan. Sejalan dengan itu, ranah dari HOTS, yaitu analisis yang merupakan kemampuan berpikir dalam menspesifikasi aspek-aspek/elemen dari sebuah konteks tertentu, evaluasi yang merupakan kemampuan berpikir dalam mengambil keputusan berdasarkan fakta/informasi; dan mengkreasi yang merupakan kemampuan berpikir dalam membangun gagasan/ide-ide.

Merujuk pada paparan tentang pembelajaran 21, gerakan literasi sekolah, salah satu upaya yang dapat dilakukan untuk mengembangkan kemampuan berpikir tingkat tinggi adalah dengan melakukan reformasi pola pembelajaran di kelas. Artinya, reformasi ilmu pendidikan di seluruh dunia berasal dari pandangan konstruktivis tentang pengajaran dan belajar. Reformasi ini secara eksplisit meminta para guru untuk mengubah strategi pengajaran mereka dengan menggeser penekanan dari pembelajaran berbasis teks tradisional dan hafalan, kepada 
eksplorasi dan pembelajaran berbasis penyelidikan yang berorientasi pada fenomena dunia nyata.

Oleh karenanya, guru hendaknya dapat mengubah pola pembelajaran secara komprehensif yang berbasis pada kemampuan berpikir tingkat tinggi dan berbasis aktivitas. Cara yang dapat dilakukan untuk mengadopsi ini adalah dengan mengembangkan perencanaan pembelajaran, pelaksanaan pembelajaran, dan penilaian autentik berbasis HOTS pada setiap pembelajaran. Namun, di dalam praktiknya pengembangan perencanaan, pelaksanaan, dan penilaian autentik berbasis HOTS bukan hal yang mudah dilaksanakan oleh guru. Selain guru harus benar-benar menguasai materi dan strategi pembelajaran, guru pun dihadapkan pada tantangan dengan lingkungan dan intake siswa yang diajarnya.

\section{Paparan Data dan Analisa}

Dokumen Silabus dan RPP yag digunakan sebagai panduan mata pelajaran Fikih kemudian dianalisa untuk mendapatkan gambaran terkait kandungan PPK, Literasi, HOTS, dan 4C.

Tabel unsur-unsur yang terkandung dalam PPK, Literasi, HOTS dan 4C

\begin{tabular}{|l|l|l|}
\hline NO & & \\
\hline 1 & PPK & $\begin{array}{l}\text { Religius, Nasionalis, Mandiri, Gotong Royong, dan } \\
\text { Integritas }\end{array}$ \\
\hline 2 & LITERASI & $\begin{array}{l}\text { Literasi Dini (Early Literacy), Literasi Dasar (Basic } \\
\text { Literacy), Literasi Perpustakaan (Library Literacy), } \\
\text { Literasi Media (Media Literacy), Literasi Teknologi } \\
\text { (Technology Literacy), Literasi Visual (Visual } \\
\text { Literacy). }\end{array}$ \\
\hline 3 & HOTS & $\begin{array}{l}\text { menganalis (membandingkan, menghubungkan, } \\
\text { membedakan, mengorganisir, menemukan makna } \\
\text { tersirat); } \\
\text { mengevaluasi (mengkritik, menafsir, membahas, }\end{array}$ \\
\hline
\end{tabular}




\begin{tabular}{|l|l|l|}
\hline & & $\begin{array}{l}\text { membuktikan); } \\
\text { mencipta (mengarang, mendesain, merangkai, } \\
\text { mengkombinasi) }\end{array}$ \\
\hline 4 & $\mathbf{4 C}$ & $\begin{array}{l}\text { Communication, Collaboration, Critical Thinking } \\
\text { and problem solving, dan Creativity and innovation. }\end{array}$ \\
\hline
\end{tabular}

\section{Silabus Mapel Fikih Kelas XII Se mester Ganjil}

Berikut paparan data analisis terhadap dokumen silabus mata pelajaran Fikih kelas XI semester ganjil di MAN 2 Pasuruan.

\begin{tabular}{|l|l|l|l|l|}
\hline KD & \multicolumn{1}{|c|}{ PPPK } & \multicolumn{1}{|c|}{ LITERASI } & \multicolumn{1}{c|}{ HOTS } \\
\hline KD 1 & Religius & $\begin{array}{l}\text { Menyimak } \\
\text { Mengamati } \\
\text { Membaca }\end{array}$ & $\begin{array}{l}\text { Memilah (C4) } \\
\text { Membandingkan } \\
\text { (C5) }\end{array}$ & $\begin{array}{l}\text { Menanggapi } \\
\text { (komunikasi ) } \\
\text { Tanya jawab } \\
\text { (komunikasi) }\end{array}$ \\
\hline KD 2 & Religious & Menyimak & $\begin{array}{l}\text { Membuat } \\
\text { langkah-langkah } \\
\text { (C4) }\end{array}$ & $\begin{array}{l}\text { Menanggapi } \\
\text { (komunikasi ) } \\
\text { Tanya jawab } \\
\text { (komunikasi) }\end{array}$ \\
\hline KD 3 & Nasionalis & Mengamati & Membaca & Membandingkan \\
(C4) & $\begin{array}{l}\text { Menanggapi } \\
\text { (komunikasi ) } \\
\text { Tanya jawab } \\
\text { (komunikasi) }\end{array}$ \\
& & Mengamati & & $\begin{array}{l}\text { Tanya jawab } \\
\text { (komunikasi) }\end{array}$ \\
\hline
\end{tabular}




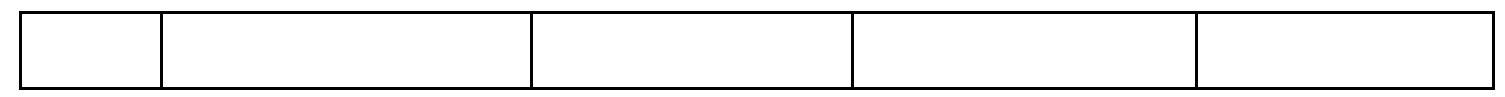

Dari paparan data analisis terhadap dokumen silabus mata pelajaran Fikih kelas XI semester ganjil tampak bahwa KD 1, 2, dan 3 memasukkan unsur PPPK, Literasi, HOTS dan 4C dalam dokumen silabus. Sedangkan KD 4 memasukkan unsur PPPK, Literasi, dan 4C saja. Unsur PPPK yang dominan adalah religius. Sedangkan yang lain kurang mendapatkan perhatian. Unsur literasi yang dimasukkan adalah menyimak (literasi dasar), mengamati (visual), dan membaca (kepustakaan). Tidak tampak literasi teknologi. Sedangkan Unsur HOTS yang diintegrasikan dalam silabus adalah $\mathrm{C} 4$ (kemampuan menganalisa) sebanyak dan C5 (kemampuan mengevaluasi). Selain itu, unsur 4C yang dominan adalah komunikasi (menanggapi, tanya jawab). Sementara Collaboration, Critical Thinking and problem solving, dan Creativity and innovation tidak tampak pada dokumen silabus.

\section{RPP Mapel Fikih Kelas XII Semester Ganjil}

Berikut paparan data analisa terhadap dokumen RPP mata pelajaran Fikih kelas XI semester ganjil di MAN2 PPT al-Yasini Pasuruan.

\begin{tabular}{|c|c|c|c|c|}
\hline RPP & PPPK & LITERASI & HOTS & $4 \mathrm{C}$ \\
\hline $\begin{array}{l}\text { RPP } \\
1\end{array}$ & Berdoa (Religius) & $\begin{array}{l}\text { Menyimak } \\
\text { Mengamati } \\
\text { Membaca }\end{array}$ & & $\begin{array}{l}\text { Menanggapi } \\
\text { (komunikasi), } \\
\text { Tanya jawab } \\
\text { (komunikasi), } \\
\text { Diskusi } \\
\text { kelompok } \\
\text { (kolaborasi) }\end{array}$ \\
\hline $\begin{array}{l}\text { RPP } \\
2\end{array}$ & Berdoa (Religius) & $\begin{array}{l}\text { Menyimak } \\
\text { Mengamati }\end{array}$ & & $\begin{array}{l}\text { Menanggapi } \\
\text { (komunikasi), } \\
\text { Tanya jawab } \\
\text { (komunikasi), }\end{array}$ \\
\hline
\end{tabular}




\begin{tabular}{|l|l|l|l|l|}
\hline & & & & $\begin{array}{l}\text { Diskusi } \\
\text { kelompok } \\
\text { (kolaborasi) }\end{array}$ \\
\hline $\begin{array}{l}\text { RPP } \\
3\end{array}$ & Berdoa (Religius) & Menyimak & & $\begin{array}{l}\text { Menanggapi } \\
\text { (komunikasi }) \\
\text { Tanya jawab } \\
\text { (komunikasi) }\end{array}$ \\
\hline $\begin{array}{l}\text { RPP } \\
4\end{array}$ & Berdoa (Religius) & Membaca & $\begin{array}{l}\text { Mensi } \\
\text { kelompok } \\
\text { (kolaborasi) }\end{array}$ \\
\hline
\end{tabular}

Dari data analisa terhadap dokumen RPP mata pelajaran Fikih kelas XI semester ganjil tampak bahwa di dalam RPP 1, 2, 3, dan 4, unsur PPPK, Literasi, dan 4C telah diintegrasikan. Namun tidak tampak unsur HOTS.

Unsur PPPK yang dominan adalah karakter religius, sementara karakter yang lain tidak tampak. Bahkan karakter nasiobalis yang terdapat dalam silabus, tidak terlihat dalam dokumen RPP. Hal ini menunjukkan adanya ketidakcermatan dalam penyusunan RPP. Unsur literasi yang dimasukkan adalah menyimak (literasi dasar), mengamati (visual), dan membaca (kepustakaan). Relatif sama dengan yang ada di dokumen silabus. Sedangkan unsur 4C, selain terdapat komunikasi, juga telah memasukkan kolaborasi. Yang janggal adalah tidak tampaknya unsur HOTS 
dalam RPP 1, 2, 3, dan 4. Baik di indikatornya, proses pembelajarannya, maupun evaluasinya (dalam bentuk tes).

Perhatikan screen-shoot indikator KD dan penilaian yang terdapat dalam RPP 1, 2, 3 , dan 4 berikut ini.

\section{Gb.1 Indikator KD 1 di RPP 1}

\begin{tabular}{|c|c|}
\hline Kompetensi Dasar & Indikator \\
\hline $\begin{array}{l}\text { 1.1. Meyakini syariat Islam tentang } \\
\text { hukum jinayat }\end{array}$ & . \\
\hline $\begin{array}{l}\text { 2.1. Menunjykkkan sikap adil dan } \\
\text { tanggung jawab dalam nenerapan } \\
\text { materi hukum jingyat }\end{array}$ & \\
\hline $\begin{array}{l}\text { 3.1. Menelagh ketentuan Allah tentang } \\
\text { ingyat dan hikmahnys }\end{array}$ & $\begin{array}{l}\text { 3.1.1. Menjelaskan dasar hukum larangan } \\
\text { membunuh } \\
\text { 3.1.2. Mengklasifikasikan macam-macam } \\
\text { pembunuhan } \\
\text { 3.1.3. Menjelaskan hukuman bagi pembunuh } \\
\text { 3.1.4. Menjelaskan dasar hukum bagi } \\
\text { pembunuh } \\
\text { 3.1.5. Menjelaskan hikmah dilarangnya } \\
\text { pembunuhan }\end{array}$ \\
\hline $\begin{array}{l}4.1 \text { Menunjulkkan sontohnelangaran } \\
\text { yang terkens } \\
\text { ketentuanj inayat }\end{array}$ & $\begin{array}{l}\text { 4.1.1. Mendemonstasikan sontoh } \\
\text { pelangagran yang terkens } \\
\text { ketentuan iinayat }\end{array}$ \\
\hline
\end{tabular}




\section{Gb. 2 Penilaian di RPP 1}

ENILAIAN

1. Jenis/teknik penilaian:

Tes Tertulis

2. Bentuk instrumen:

1). Jelaskan dasar hukum larangan membunuh!

2). Klasifikasikan macam-macam pembunuhan!

3). Jelaskan hukuman bagi pembunuh!

4). Jelaskan das ar hukum bagi pembunuh!

5). Jelaskan hikmah dilarangnya pembunuhan!

Kunci Jauxaban:

(terlampir dimateri)

3. Pedoman penskoran

Penskoran:

Skor 5 jika jawaban benar

Skor 3 jika jawaban kurang benar

Skor 1 jika jawaban tidak benar/tidak menjawab

Pasuruan, 15 Juli 2019

Gb. 3 Indikator KD 2 di RPP 2

\begin{tabular}{|c|c|}
\hline Kompetensi Dasar & Indikator \\
\hline \multirow{2}{*}{\multicolumn{2}{|c|}{$\begin{array}{l}1.2 \text { Meyakini syariat Islam tentang hukum } \\
\text { hudud } \\
2.2 \text { Membias akan sikap adil dan tanggung } \\
\text { jawab dr eri hukum hudud }\end{array}$}} \\
\hline & \\
\hline hod $\quad$ LOTS & $\begin{array}{l}\text { 3.2.1 Menjelaskan pengertian hudud } \\
\text { 3.2.2 Mruvebuthan macam - macam hudud } \\
\text { 3.2.3 Menjelaskan ketentuan hulkum Allah } \\
\text { tentang hudud }\end{array}$ \\
\hline $\begin{array}{l}\text { t.2 Menyajikan contoh pelanggaran yang } \\
\text { terkena ketentuan hudud }\end{array}$ & $\begin{array}{l}\text { 4.2.1 Menyaiikan sontoh akibat orang yang } \\
\text { melangegr ketentuan hudud. }\end{array}$ \\
\hline
\end{tabular}

Gb. 4 Penilaian di RPP 2

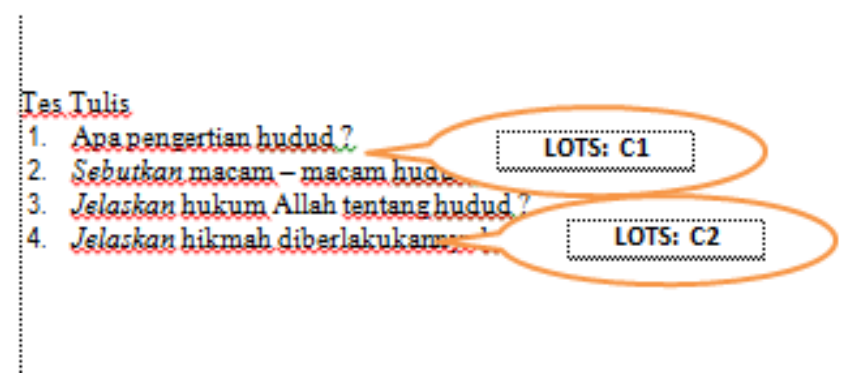


Gb. 5 Indikator KD 3 di RPP 3

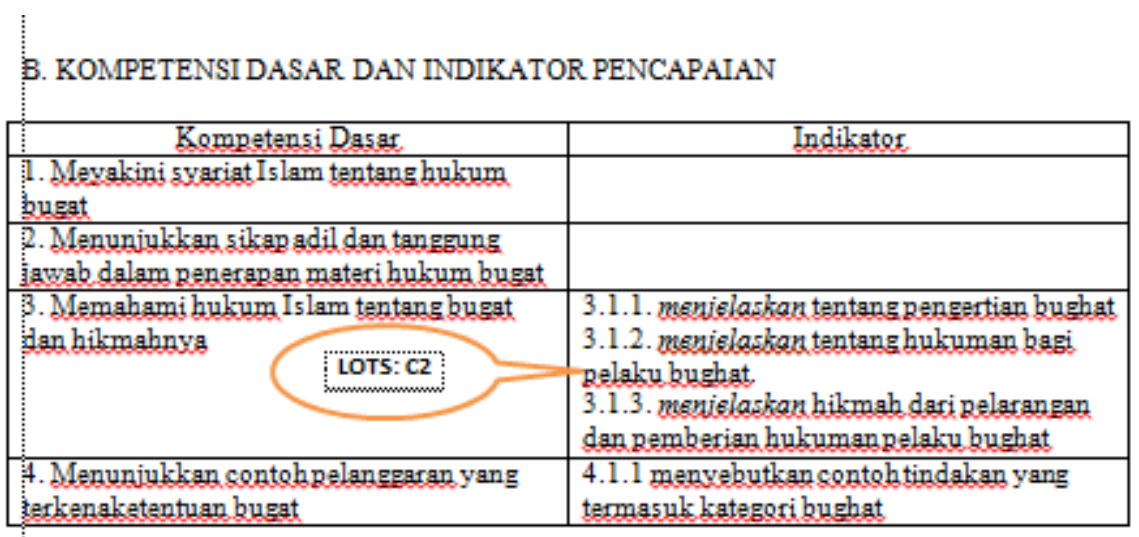

Gb. 6 Penilaian di RPP 3

\footnotetext{
a. Tes Tulis bentuk uraian

1. jelaskan nengertian bughat secara bahas a dan istilah!

2. sebutbonjenis 2 bughat!

3. sebuthan sara mengatas i bughat berdas arkan ienisnva!

4. sekutkan hilmah pelarangan bughat!
}

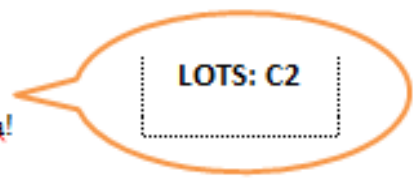

Kunci jawaban:

1.
2.
4.

Gb.7 Indikator KD 4 di RPP 4 


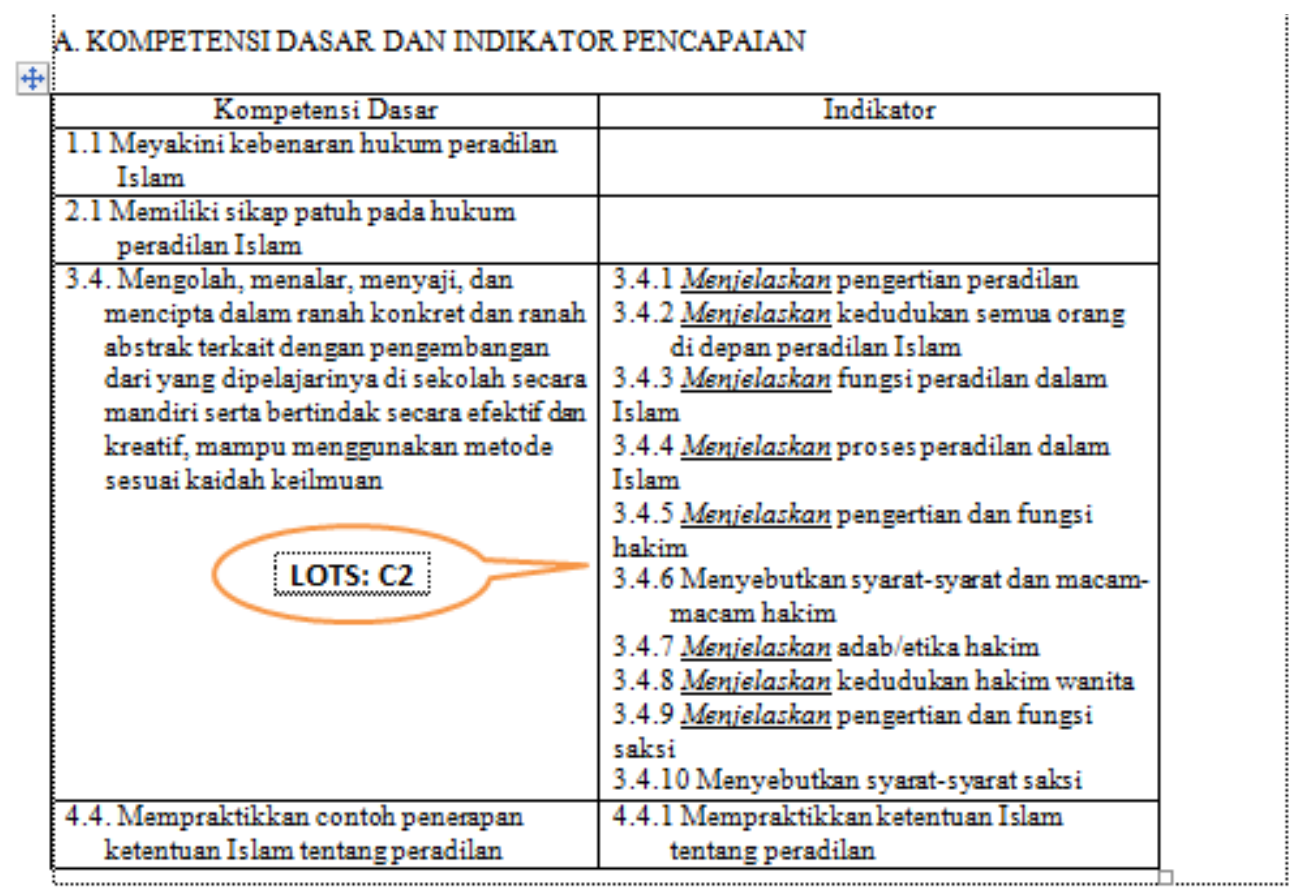

\section{Gb. 8 Penilaian di RPP 4}

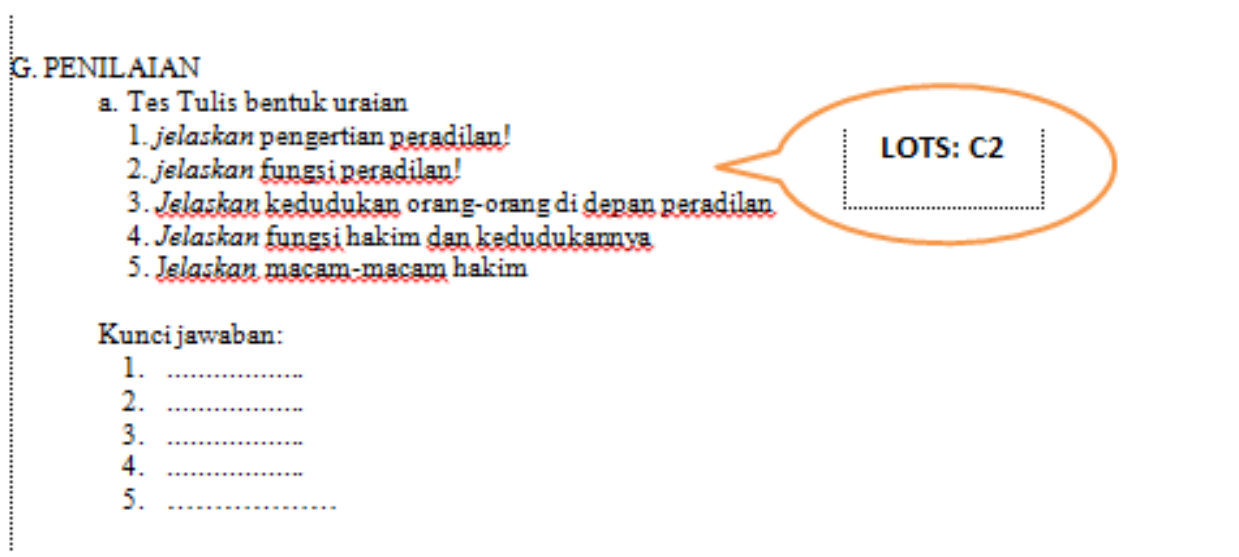

Semua data screen-shot menunjukkan bahwa unsur HOTS tidak diintegrasikan di dalam Rencana Program Pengajaran (RPP).

Dari data-data analisis unsur PPK, Literasi, HOTS dan 4C pada dokumen silabus dan RPP mata pelajaran Fikih Kelas XII Semester ganjil di atas, dapat diambil beberapa kesimpulan:

1. Terdapat ketidaksesuaian antara dokumen silabus dan RPP. 
Hal ini mengindikasikan adanya ketidaktelitian dalam penyusunan RPP. Dokumen RPP semestinya ditulis dengan merujuk kepada dokumen silabus.

2. Unsur PPK yang tampak jelas dan dominan hanya karakter religius.

Walaupun hal ini menunjukkan sebagian sisi positif, akan tetapi masih jauh dari kata ideal. Karakter religius masih sebatas berdoa sebelum memulai dan setelah mengakhiri pelajaran. Selain itu, karakter-karakter yang lain belum mendapatkan perhatian yang cukup. Karakter nasionalis penting untuk diintegrasikan dalam proses pembelajaran agar peserta didik tumbuh menjadi pribadi yang mencintai negara dan bangsanya. Kemandirian adalah modal utama untuk menjadi bangsa yang maju yang ditandai dengan berkurangnya ketergantungan kepada bangsa dan negera lain. Sementara karakter gotong royong mutlak diperlukan untuk mempersatukan segenap potensi dari anak bangsa yang memiliki latar belakang sangat beragam baik dari sisi bahasa, suku, maupun agama. Sedangkan integritas merupakan karakter utama untuk membangun sumber daya manusia yang unggul. Sebagaimana yang kita ketahui bersama bahwa problem integritas menimbulkan permasalahan yang besar bagi bangsa dan Negara. Salah satunya adalah budaya korupsi yang merajalela di berbagai bidang dan tingkat pemerintahan.

3. Literasi sudah mendapatkan perhatian yang cukup, walaupun belum beragam.

Baru sebatas literasi daras dan kepustakaan. Literasi teknologi belum tersentuh. Di zaman yang teknologi berkembang pesat seperti saat ini, peserta didik perlu dibekali kecapakan berpikir dan kecakapan teknis terkait literasi teknologi agar mereka mampu memanfaatkan teknologi untuk hal-hal yang bernilai positif.

4. Unsur HOTS (high order thingking skills) kurang mendapatkan perhatian.

Padahal kecakapan HOTS ini sangat dibutuhkan oleh peserta didik di kehidupan sekarang maupun di masa yang akan datang. Era sekarang bisa disebut sebagai era revolusi informasi di mana dengan berkembangnya teknologi berbasis internet yang begitu cepat, informasi merupakan suatu hal yang membanjiri kehidupan manusia modern. Informasi tersebut tidak 
semuanya valid, banyak juga yang berupa hoaks, kabar palsu. Tanpa kemampuan analisis yang memadai, seseorang akan menjadi korban dari banjirnya informasi tersebut. Dan efek negative dari hal tersebut bisa kita rasakan saat ini di mana orang begitu mudahnya menyebarkan berita hoaks yang seringkali menimbulkan kekisruhan dan kerusuhan di masyarakat.

5. Unsur 4C baru sebatas komunikasi dan kolaborasi.

Sementara Critical Thinking and problem solving, dan Creativity and innovation tidak mendapatkan perhatian. Padahal 2 aspek ini sangat dibutuhkan oleh peserta didik untuk menghadapi kehidupan nyata. Apalagi zaman sekarang merupakan zaman disrupsi, zaman kesemrawutan. Kemampuan berpikir kritis, problem solving, kreatif, dan inovatif merupakan suatu keharusan agar bisa menghadapi berbagai tantangan kehidupan.

\section{Simpulan}

Dokumen RPP mata pelajaran Fikih kelas $\mathrm{X}$ semster ganjil MAN 2 Pasuruan tidak sinkron dengan dokumen silabusnya. Hal ini mengindikasikan adanya ketidaktelitian dalam penyusunan RPP yang seharusnya berdasarkan dokumen silabus. Unsur PPK yang terintegrasi dalam silabus dan RPP masih terbatas pada karakter religius. Karakter nasionalis, mandiri, gotong royong, dan integritas tidak mendapatkan perhatian. Unsur literasi sudah cukup mendapatkan perhatian. Sedangkan unsur 4C baru sebatas komunikasi dan kolaborasi. Sementara berpikir kritis dan kreatifitas belum mendapatkan perhatian. Yang paling disayangkan adalah tidak ditemukannya unsur HOTS dalam RPP, baik di indikator KD, proses pembelajaran, maupun penilaian. Padahal kemampuan berpikir tingkat tinggi ini sangat diperlukan oleh peserta didik untuk berkembang dan menghadapi tantangan dunia nyata. 


\section{Daftar Pustaka}

Ainurrahman. 2009. Belajar dan Pembelajaran. Bandung: Alfabeta.

Arifin, Zaenal. 2017. Mengembangkan Instrumen Pengukur Critical Thinking Skills Siswa pada Pembelajaran Matematika Abad 21. Jurnal THEOREMS, Volume 1, Nomor 2.

Ash Shiddieqy, Hasbi. 1987. Pengantar Ilmu Fiqh. Jakarta : Bulan Bintang.

Depag RI Ditjen Kelembagaan Agama Islam. 2004. Kurikulum 2004; Pedoman Khusus Fiqih MTs. Jakarta: Depag.

Departemen Agama RI. 2004. Kurikulum 2004 Standar Kompetensi MTs. Jakarta :

Depag.

Firmansyah (Kepala Madrasah) dan Moch. Saiful Haris (Guru Fikih) MAN 2 Pasuruan. Wawancara oleh Fatimah pada tanggal 29 Pebruari 2020.

KMA No. 183 dan 184 Tahun 2019

Kunandar, 2011. Guru Profesional (Implementasi Kurikulum Tingkat Satuan Pendidikan dan

Sukses dalam Sertifikasi Guru). Jakarta: Raja Grafindo Persad.

Majid, Abdul. 2006. Perencanaan Pembelajaran. Bandung: PT Rosdakarya.

PERPRES Nomor 87 Tahun 2017

Purwanto, Ngalim. 2000. Psikologi Pendidikan. Bandung: PT. Remaja Rosdakarya.

Prihadi, Singgih. 2017. Penguatan Ketrampilan Abad 21 Melalui Pembelajaran Mitigasi

Bencana Banjir. Prosiding Seminar Nasional Pendidikan Geografi FKIP UMP.

Razak, Nasrudin. 1985. Dienul Islam. Bandung : Al-Ma'arif.

Rustaman, N.Y. 2007. Kemampuan Dasar Bekerja Ilmiah dalam Pendidikan Sains dan Asesmennya. Proceeding of the First International on Science Education. Bandung: Sps UPI.

Salinan KMA 183 tahun 2019, Kurikulum PAI dan Bahasa Arab pada Madrasah

Sanjaya, Wina. Strategi Pembelajaran. Jakarta: Kencana Prenada Group.

Thoha, Chabib dan Abdul Mu'ti. 1998. PHM-PAI di Sekolah Eksistensi dan Proses Belajar

Mengajar Pendidikan Agama Islam. Yogyakarta: Pustaka Belajar.

Tim Penyusun PPK. 2016. Panduan Penilaian Penguatan Pendidikan Karakter Tingkat 
Fatimah, Muhtar Tajuddin, Muhammad Ilyas, Abdul Majid

Sekolah Dasar dan Sekolah Menengah Pertama. Jakarta: Kementerian Pendidikan dan Kebudayaan Republik Indonesia.

UU RI tentang Sistem Pendidikan Nasional No. 20 Tahun 2003. 